\title{
DESIGN WIRE CONNECTION GROUP INSPECTION EQUIPMENT OF THREE PHASE TRANSFORMERS BASED ON TWO VOLTMETER METHOD AND DATA PROCESSING USING NEURAL NETWORK
}

\author{
Cao Xuan Tuyen \\ TNU University of Technology
}

\section{ABSTRACT}

The identification of the wire connection group of three-phase transformers (WCGTT) is an important step in the entire process of inspection, testing transformers. This is particularly important for the coupling transformers when they are working in parallel or we consider the phase angle of the supply voltage for the control circuit. However, nowadays, mostly in the central laboratory of the electricity corporations are conducting structure determined by the method of wiring craft, inaccurate, time consuming and require the high care technician. To overcome this drawback, this paper offers the design a wire connection group inspection equipment of three phase transformers based on two voltmeter method and data processing using neural network is designed. The results of testing this equipment show that, the equipment works reliably, exactly.

Keywords: the wire connection group; the two voltmeter method; Neural network, three-phase transformers; Data Acquisition module.

Received: 23/5/2019; Revised: 05/6/2019; Published: 06/6/2019

\section{XÂY DỰNG HỆ THỐNG KIỂM TRA TỔ NỐI DÂY CỦA MÁY BIẾN ÁP BA PHA TRÊN CƠ SỞ PHƯƠNG PHÁP SỦ DỤNG HAI VÔN KẾ VÀ XỬ LÝ SỐ LIỆU SỦ DỤNG NEURAL NETWORK}

\author{
Cao Xuân Tuyển \\ Truòng Đại học Kỹ thuật Công nghiệp - ĐH Thái Nguyên
}

\section{TÓM TĂT}

Việc xác định, (kiểm tra) tổ nối dây của máy biến áp ba pha là một khâu quan trọng trong toàn bộ qui trình kiểm tra, thử nghiệm máy biến áp. Điều này có ý nghĩa đặc biệt quan trọng khi ghép các máy biến áp (MBA) làm việc song song hay khi cần quan tâm tới góc pha điện áp cấp cho các mạch điều khiển. Tuy nhiên, ở Việt Nam hiện nay, hầu hết ở các trung tâm thí nghiệm thuộc các tổng công ty điện lực đều tiến hành xác định tổ nối dây theo phương thức thủ công, không chính xác, mất nhiều thời gian và yêu cầu sự cẩn thận cao của kỹ thuật viên. Để khắc phục nhược điểm này, bài báo đưa ra việc thiết kế thiết bị kiểm tra tổ nối dây máy biến áp ba pha trên cơ sở phương pháp sử dụng hai vôn kế và sử dụng mạng nơ ron để sử lý số liệu. Kết quả kiểm tra thiết bị cho thấy thiết bị làm việc chính xác và tin cậy.

Từ khóa: Thiết bị xác định tổ nối dây máy biến áp ba pha; Phương pháp hai vôn kế; mạng no ron; máy biến áp ba pha; khối thu thập dũ liệu.

Ngày nhận bài: 23/5/2019; Ngày hoàn thiện: 05/6/2019; Ngày đăng: 06/6/2019

Email: tuyenkdmd@gmail.com

DOI: https://doi.org/10.34238/tnu-jst.2019.10.1583 


\section{Introductions}

The power transformer is the important and necessary equipment for the national electrical power transmission and distribution system.

With the purpose of guaranteeing the continuity in supplying electrical power and decreasing the standby equipments, the operating power losses, we let transformers work in parallel. One of the conditions of parallel operation of transformers is that, they have the same wire connection group (vector group), Therefore, inspection of wire connection group of three phase transformers is a necessary step. Nowadays, to inspect the wire connection group of three phase transformers, we use following methods: Polarity, Wattmeter., Phasormeter or vectormeter, Two voltmeter.

The way of inspecting the wire connection group of three phase transformers based on above methods now is non-automatical, and spends a lot of time, sometimes, is not completely accurate. To overcome above problems, in this paper, a wire connection group inspection equipment of three phase transformers based on two voltmeter method and data processing using neural network is designed. With this equipment, the wire connection group of three phase transformers is identified automatically and exactly by using computer, Data Acquisition module, the software of Labvolt company and an appropriate data processing method based on neural network.

\section{Prinscple of inspecting the wire connection group of three phase transformers based on two voltmeter method}

In order to inspect the wire connection group of three phase transformers based on two voltmeter method, according to [1], [2], [3], two voltmeter are used and connected to a three phase transformer as shown in figure 1 .

Also according to [1], [2], [3], a voltage of $100 \mathrm{~V}$ or $200 \mathrm{~V}$ is supplied to high voltage windings or low voltage windings and is measured by voltmer $\mathrm{V}_{1}$. Using voltmeter $\mathrm{V}_{2}$ to measure $\mathrm{U}_{\mathrm{bB}}, \mathrm{U}_{\mathrm{bC}}, \mathrm{U}_{\mathrm{cC}}, \mathrm{U}_{\mathrm{cB}}$, if the measured values of $\mathrm{U}_{\mathrm{b} \boldsymbol{B}}, \mathrm{U}_{\mathrm{bC}}, \mathrm{U}_{\mathrm{cC}}, \mathrm{U}_{\mathrm{cB}}$ are equal to the their calculated values corresponding with one of twelve wire connection groups, the wire connection group of three phase transformer is identified.

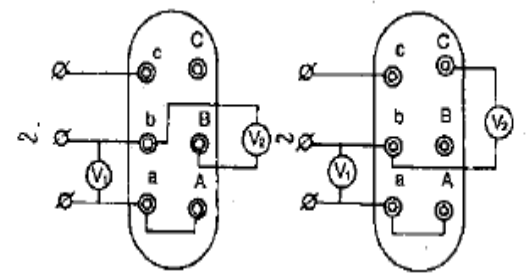

Figure 1. The diagram of using two voltmeters to inspect the the wire connection group of threephase transformers(WCGTT)

The method to calculate values of $\mathrm{U}_{\mathrm{bB}}, \mathrm{U}_{\mathrm{bC}}$, $\mathrm{U}_{\mathrm{cC}}, \mathrm{U}_{\mathrm{cB}}$ corresponding with different wire connection groups is described as below:

- Three phase transformer has $Y / Y-12$
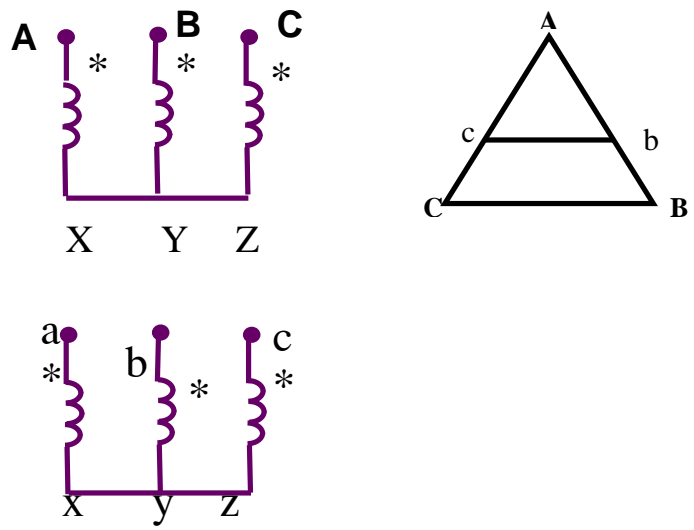

Figure 2. The wire connection and vetor diagram of three phase transformers with $Y / Y-12$

To caculate $U_{b B}$ :

From triangulars $\mathrm{ABC}$ and abc, we have:

$b B=A B-a b$

From (1), we have:

$$
\frac{\overline{b B}}{\overline{a b}}=\frac{\overline{A B}}{\overline{a b}}-1=K-1 ; K=\frac{\overline{A B}}{\overline{a b}}
$$

With $U=\overline{a b}$, we have:

$$
U_{b B}=U(K-1) .
$$

To caculate $U_{b C}$ and $U_{c B}$ :

From the triangular $\mathrm{AbC}$, we have: 


$$
\begin{aligned}
& \overline{b C}^{2}=\overline{A C}^{2}+\overline{a b}^{2}-2 \overline{a b} \overline{A C} \cos 60^{0}= \\
& =\overline{A B}^{2}+\overline{a b}^{2}-\overline{a b} \overline{A B}=-\overline{a b} 2\left(1-\frac{\overline{A B}}{\overline{a b}}+\left(\frac{\overline{A B}}{\overline{a b}}\right)^{2}\right)
\end{aligned}
$$

From (4), we have:

$$
U_{b C}=U_{c B}=U \sqrt{1-K+K^{2}}
$$

- Three phase transformer has $Y / Y-6$
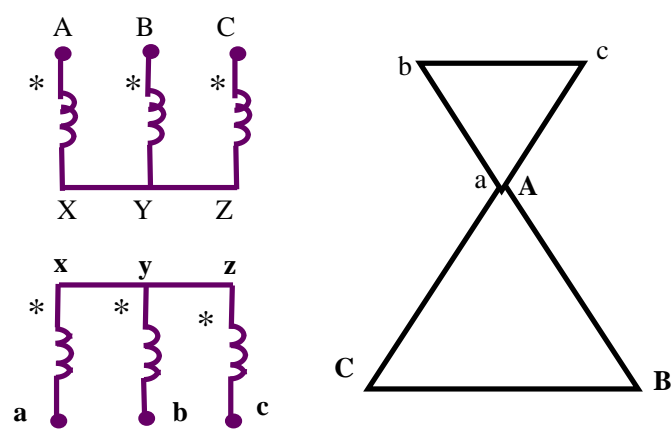

Figure 3. The wire connection and vetor diagram of three phase transformers with $Y / Y-6$

To caculate $U_{b B}$ :

From triangulars $\mathrm{ABC}$ and abc in figure 3, we have:

$$
U_{b B}=\overline{b a}+\overline{A B}=U+K U=U(K+1)
$$

To caculate $U_{b C}$ and $U_{c B}$ :

From figure 3 , we consider triangular abC, we have:

$$
\begin{aligned}
\overline{b C}^{2} & =\overline{A C}^{2}+\overline{a b}^{2}-2 \overline{a b} \overline{A C} \cos 120^{\circ}= \\
& =\overline{A B}^{2}+\overline{a b}^{2}+\overline{a b} \overline{A B}= \\
& =\overline{a b}^{2}\left(1+\frac{\overline{A B}}{\overline{a b}}+(\overline{\overline{A B}})^{2}\right)
\end{aligned}
$$

From (7), we have:

$$
U_{b C}=U_{c B}=U \sqrt{1+K+K^{2}}
$$

By the same way, we caculate values of $\mathrm{U}_{\mathrm{bB}}$, $\mathrm{U}_{\mathrm{bC}}, \mathrm{U}_{\mathrm{cC}}, \mathrm{U}_{\mathrm{cB}}$ corresponding with 12 wire connection groups as shown in table 1 .
Table 1. The values of $U_{b B}, U_{c C}, U_{b C}, U_{c B}$ corresponding with different wire connection groups of three phase transformers

\begin{tabular}{cccc}
\hline WC & \multicolumn{3}{c}{ Line votages } \\
\cline { 2 - 4 } GTT & $\mathbf{U}_{\mathbf{b B}} ; \mathbf{U}_{\mathbf{c C}}$ & $\mathbf{U}_{\mathbf{b C}}$ & $\mathbf{U}_{\mathbf{c B}}$ \\
\hline 12 & $\mathrm{U}(\mathrm{K}-1)$ & $U \sqrt{1-K+K^{2}}$ & $U \sqrt{1-K+K^{2}}$ \\
11 & $U \sqrt{\left(1-\sqrt{3} K+K^{2}\right)}$ & $U \sqrt{1+K^{2}}$ & $U \sqrt{\left(1-\sqrt{3} K+K^{2}\right)}$ \\
10 & $U \sqrt{1-K+K^{2}}$ & $U \sqrt{\left(1+K+K^{2}\right)}$ & $U(K-1)$ \\
9 & $U \sqrt{1+K^{2}}$ & $U \sqrt{\left(1+\sqrt{3} K+K^{2}\right)}$ & $U \sqrt{\left(1-\sqrt{3} K+K^{2}\right)}$ \\
8 & $U \sqrt{1+K+K^{2}}$ & $U(K+1)$ & $U \sqrt{1-K+K^{2}}$ \\
7 & $U \sqrt{\left(1+\sqrt{3} K+K^{2}\right)}$ & $U(K+1)$ & $U \sqrt{1+K^{2}}$ \\
6 & $U(K+1)$ & $U \sqrt{1+K+K^{2}}$ & $U \sqrt{1+K+K^{2}}$ \\
5 & $U \sqrt{\left(1+\sqrt{3} K+K^{2}\right)}$ & $U \sqrt{1+K^{2}}$ & $U \sqrt{\left(1+\sqrt{3} K+K^{2}\right)}$ \\
4 & $U \sqrt{1+K+K^{2}}$ & $U \sqrt{\left(1-K+K^{2}\right)}$ & $U(K+1)$ \\
3 & $U \sqrt{1+K^{2}}$ & $U \sqrt{\left(1-\sqrt{3} K+K^{2}\right)}$ & $U \sqrt{\left(1+\sqrt{3} K+K^{2}\right)}$ \\
2 & $U \sqrt{\left(1-K+K^{2}\right)}$ & $U(K-1)$ & $U \sqrt{\left(1+K+K^{2}\right)}$ \\
1 & $U \sqrt{\left(1-\sqrt{3} K+K^{2}\right)}$ & $U \sqrt{\left(1-\sqrt{3} K+K^{2}\right)}$ & $U \sqrt{\left(1+K^{2}\right)}$ \\
\hline
\end{tabular}

3. Design a wire connection group inspection equipment of three phase transformers based on two voltmeter method and data processing using neural network is designed.

\subsection{Schematic circuits}

Schematic circuits of the equipment is shown in figure 4.

In the schematic circuits of the equipment, TPT is the three phase transformer, that we need identify the wire connection group. A voltage of $200 \mathrm{~V}$ is supplied low voltage windings of TPT. The leads of TPT windings are connected with the inputs of the Data Acquisition module. The Data Acquisition module is connected with the computer PC. The Data Acquisition software of LABVOLT company is installed in the computer PC. This software reads the line voltages of three phase transformer, that we need for identification of the wire connection group of TPT, and save them in the memory of the PC for data processing using neural network. 


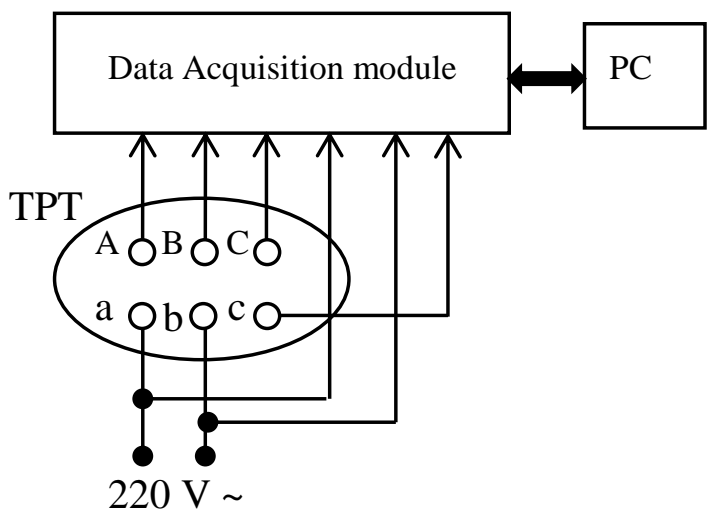

Figure 4. The Schematic circuit of the equipment

\subsection{Algorith for identifying wire connection group}

The algorith for identifying the wire connection group of three phase transformers is shown in figure 5 .

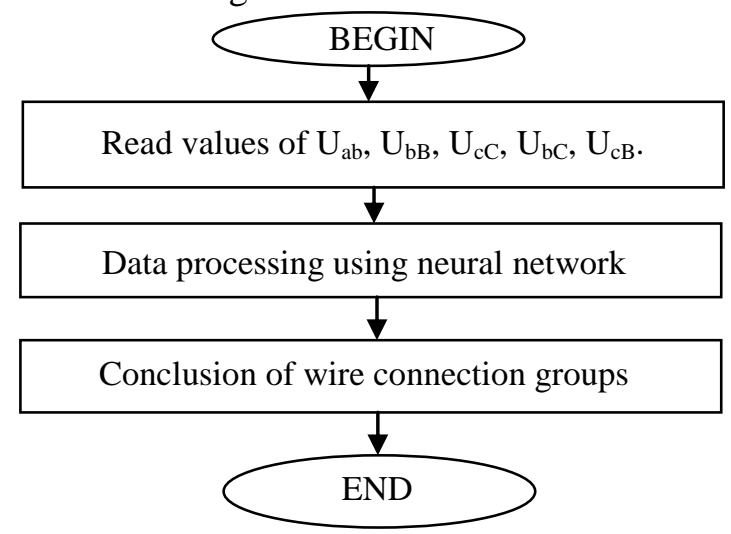

Figure 5. The algorith for identifying the wire connection group of three phase transformers

\subsection{Design and assemble the equipment.}

The equipment is designed and assembled at division of Electrical Equipment, Faculty of Electrical Engineering, Thai Nguyen University of Technology, Vietnam.

The picture of the equipment is shown in figure 6 .

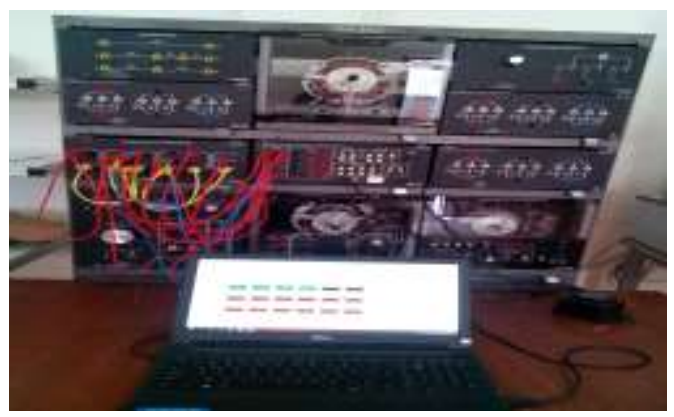

Figure 6. The picture of the equipment

\subsection{Data processing using neural network}

The wire connection group inspection equipment of three phase transformers is used to collect data of votages $\mathrm{U}_{\mathrm{bB}}, \mathrm{U}_{\mathrm{cC}}, \mathrm{U}_{\mathrm{bC}}, \mathrm{U}_{\mathrm{cB}}$. Each time we do the data acquisition, we get different values of votages $\mathrm{U}_{\mathrm{bB}}, \mathrm{U}_{\mathrm{cC}}, \mathrm{U}_{\mathrm{bC}}, \mathrm{U}_{\mathrm{cB}}$. These different values of votages $\mathrm{U}_{\mathrm{bB}}, \mathrm{U}_{\mathrm{cC}}$, $\mathrm{U}_{\mathrm{bC}}, \mathrm{U}_{\mathrm{cB}}$ close to their values that are calculated by formulas in table 1 . The reasons of that differences maybe are mistakes of the equipment, changes of the line votage. So we must do the next step, that is data processing using neural network. To do this, we arrange data of votages $\mathrm{U}_{\mathrm{bB}}, \mathrm{U}_{\mathrm{cC}}, \mathrm{U}_{\mathrm{bC}}, \mathrm{U}_{\mathrm{cB}}$ in the way as shown in table 2 for the wire connection group of 1, table 3 for the wire connection group of 2. table 4 for the wire connection group of 3, table 5 for the wire connection group of 4 , table 6 for the wire connection group of 5, table 7 for the wire connection group of 6. The data of votages $\mathrm{U}_{\mathrm{bB}}, \mathrm{U}_{\mathrm{cC}}, \mathrm{U}_{\mathrm{bC}}$, $\mathrm{U}_{\mathrm{cB}}$ of other wire connection groups are arranged similarly.

Table 2. The data of votages $U_{b B}, U_{c C}, U_{b C}, U_{c B}$ corresponding with the wire connection group of 1 .

\begin{tabular}{cccccc}
\hline Times & $\mathbf{1}$ & $\mathbf{2}$ & $\mathbf{3}$ & $\mathbf{4}$ & $\mathbf{5}$ \\
\hline $\mathrm{U}_{\mathrm{bB}}$ & 330 & 333 & 328 & 326 & 336 \\
$\mathrm{U}_{\mathrm{cC}}$ & 330 & 333 & 328 & 326 & 336 \\
$\mathrm{U}_{\mathrm{bC}}$ & 330 & 333 & 328 & 326 & 336 \\
$\mathrm{U}_{\mathrm{cB}}$ & 439 & 442 & 438 & 436 & 443 \\
WCGTT & 1 & 1 & 1 & 1 & 1 \\
\hline
\end{tabular}

Table 3. The data of votages $U_{b B}, U_{c C}, U_{b C}, U_{c B}$ corresponding with the wire connection group of 2 .

\begin{tabular}{cccccc}
\hline Times & $\mathbf{1}$ & $\mathbf{2}$ & $\mathbf{3}$ & $\mathbf{4}$ & $\mathbf{5}$ \\
\hline $\mathrm{U}_{\mathrm{bB}}$ & 331 & 333 & 329 & 327 & 335 \\
$\mathrm{U}_{\mathrm{cC}}$ & 331 & 333 & 329 & 327 & 335 \\
$\mathrm{U}_{\mathrm{bC}}$ & 161 & 163 & 158 & 156 & 165 \\
$\mathrm{U}_{\mathrm{cB}}$ & 526 & 528 & 524 & 522 & 530 \\
WCGTT & 2 & 2 & 2 & 2 & 2
\end{tabular}

Table 4. The data of votages $U_{b B}, U_{c C}, U_{b C}, U_{c B}$ corresponding with the wire connection group of 3 .

\begin{tabular}{cccccc}
\hline Times & $\mathbf{1}$ & $\mathbf{2}$ & $\mathbf{3}$ & $\mathbf{4}$ & $\mathbf{5}$ \\
\hline $\mathrm{U}_{\mathrm{bB}}$ & 440 & 442 & 438 & 436 & 443 \\
$\mathrm{U}_{\mathrm{cC}}$ & 440 & 442 & 438 & 436 & 443 \\
$\mathrm{U}_{\mathrm{bC}}$ & 220 & 222 & 218 & 216 & 223 \\
$\mathrm{U}_{\mathrm{cB}}$ & 582 & 584 & 579 & 577 & 586 \\
WCGTT & 3 & 3 & 3 & 3 & 3 \\
\hline
\end{tabular}


Table 5. The data of votages $U_{b B}, U_{c C}, U_{b C}, U_{c B}$ corresponding with the wire connection group of 4 .

\begin{tabular}{cccccc}
\hline Times & $\mathbf{1}$ & $\mathbf{2}$ & $\mathbf{3}$ & $\mathbf{4}$ & $\mathbf{5}$ \\
\hline $\mathrm{U}_{\mathrm{bB}}$ & 526 & 528 & 524 & 522 & 530 \\
$\mathrm{U}_{\mathrm{cC}}$ & 526 & 528 & 524 & 522 & 530 \\
$\mathrm{U}_{\mathrm{bC}}$ & 331 & 333 & 329 & 327 & 335 \\
$\mathrm{U}_{\mathrm{cB}}$ & 601 & 603 & 598 & 596 & 605 \\
WCGTT & 4 & 4 & 4 & 4 & 4 \\
\hline
\end{tabular}

Table 6. The data of votages $U_{b B}, U_{c C}, U_{b C}, U_{c B}$ corresponding with the wire connection group of 5 .

\begin{tabular}{cccccc}
\hline Times & $\mathbf{1}$ & $\mathbf{2}$ & $\mathbf{3}$ & $\mathbf{4}$ & $\mathbf{5}$ \\
\hline $\mathrm{U}_{\mathrm{bB}}$ & 582 & 584 & 579 & 577 & 586 \\
$\mathrm{U}_{\mathrm{cC}}$ & 582 & 584 & 579 & 577 & 586 \\
$\mathrm{U}_{\mathrm{bC}}$ & 440 & 442 & 438 & 436 & 443 \\
$\mathrm{U}_{\mathrm{cB}}$ & 582 & 584 & 579 & 577 & 586 \\
WCGTT & 5 & 5 & 5 & 5 & 5 \\
\hline
\end{tabular}

Table 7. The data of votages $U_{b B}, U_{c C}, U_{b C}, U_{c B}$ corresponding with the wire connection group of 6 .

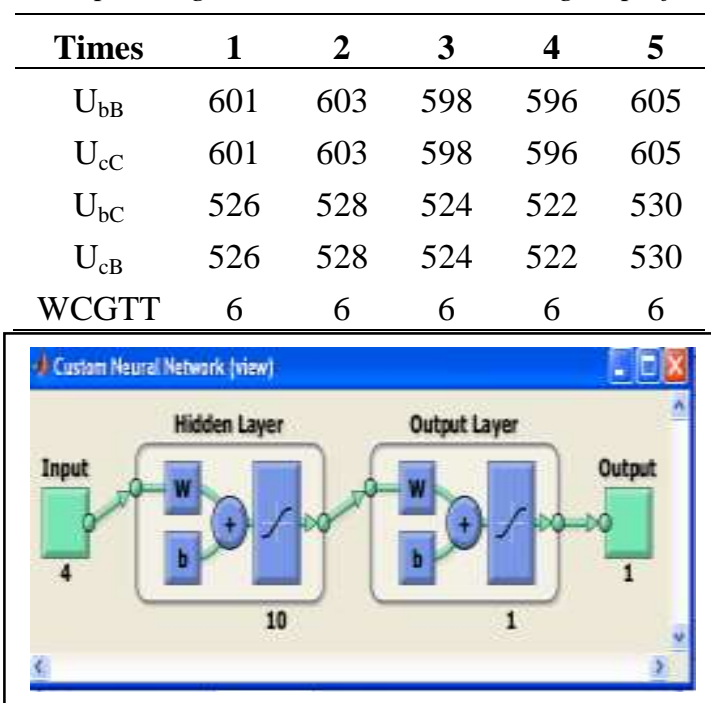

Figure 7. The neural network with two layers

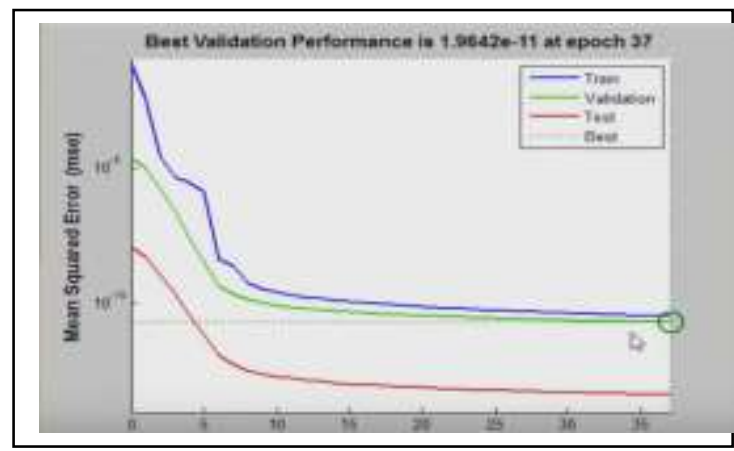

Figure 8. The error of training
We use the neural network tool in Matlab to process data with two layers that is shown in figure 7 . The error of training is shown in figure 8. The results of data processing using neural network tool in matlab is shown in table 8 .

Table 8. The results of data processing using neural network tool in matlab

\begin{tabular}{cc}
\hline Values of $\mathbf{U}_{\mathbf{b B}}, \mathbf{U}_{\mathbf{b C}}, \mathbf{U}_{\mathbf{c C}}, \mathbf{U}_{\mathbf{c B}}$ & WCGTT \\
\hline WCGTT ([330,330,330,439]') & 1 \\
WCGTT ([331,331,161,526]') & 2 \\
WCGTT ([440,440,220,582]') & 3 \\
WCGTT ([526,526,331,601]') & 4 \\
WCGTT ([582,582,440,582]') & 5 \\
WCGTT ([601,601,526,526]') & 6 \\
WCGTT ([582,582,601,440]') & 7 \\
WCGTT ([526,526,601,331]') & 8 \\
WCGTT ([440,440,582,220]') & 9 \\
WCGTT ([331,331,526,161]') & 10 \\
WCGTT ([220,220,440,220]') & 11 \\
WCGTT $\left.[161,161,331,331]^{\prime}\right)$ & 12 \\
\hline
\end{tabular}

The results show that, with the sample of data of values of votages $\mathrm{U}_{\mathrm{bB}}, \mathrm{U}_{\mathrm{cC}}, \mathrm{U}_{\mathrm{bC}}, \mathrm{U}_{\mathrm{cB}}$ in table 2, after data processing, we have the wire connection group of three phase transformers exactly. With other samples, we also have similar results.

\section{Conclusions}

The design a wire connection group inspection equipment of three phase transformers based on two voltmeter method and data processing using neural network is designed and implemented successfully. Experimental results show that, the equipment works exactly, reliably.

\section{REFERENCES}

[1]. Nguyen Duc Sy, Technology of manufacturing electrical equipments, The educational publisher, Hanoi, 2007.

[2]. Nguyen Duc Sy, Technology of manufacturing electrical machines and transformers, The educational publisher, Hanoi, 1995.

[3]. Tran Khanh Ha, Phan Tu Thu, Nguyen Van Sau. Electrical machines 1,2. The Science technic publisher, Hanoi, 2006. 
